\title{
論文
}

\section{Relationship between Swollen Network Structure of Rubber Vulcanizates and Freezing Point Depression of Swelling Solvent}

\author{
by \\ Hidetoshi Oikawa and Kenkichi Murakami* \\ Chemical Research Institute of Non-Aqueous Solutions, Tohoku University, \\ 2 chome, Katahira, Sendai, Miyagi 980
}

Rubber vulcanizates in the state of swelling equilibrium with benzene were cooled, and the freezing point depressions $(F P D)$ were measured. It was found that the $F P D$ of the crosslinked rubber sample was larger than that of the uncrossliked one at the same concentration. For polydimethylsiloxane the FPD of bimodal network was larger than that of unimodal network. Here the bimodal network means the network prepared by the end-linking of two prepolymers having different average molecular weights; it has a wider distribution in mesh size of network (chain weights between crosslinking points) than the unimodal network, and may be regarded as a model of the inhomogeneous network. Thus, the result suggests that the inhomogeneity of the network structure can be detected by the cryoscopic method.

For uncrosslinked rubber systems the larger $F P D$ was observed with increasing concentration, decreasing molecular weight, and decreasing $\chi$-parameter. Though we may qualitalively explain these features by the Flory-Huggins lattice model, we observemore complex behavior: the compressive moduli of swollen rubber vulcanizates decreased with lowering temperature, and fell rapidly from a certain value to zero when the sample freezes. This may be considered to be associated with a phase transition phenomenon.

With lowering temperature, the intrinsic viscosity of rubber solutions decreased and the content of benzene in swollen samples decreased. Swollen samples became turbid in the vicinity of $283 \mathrm{~K}$. The result may suggest that with lowering temperature the concentration fluctuation becomes large as the solvent becomes poor. By further cooling, it is considered that crystallization of benzene occurs first and then the swollen samples freezes and contracts.

\section{膨潤加硫ゴムの網目構造と膨潤媒の水点降下度との関連性}

$$
\text { 及川英 俊 - 村上 謙 吉* }
$$

(原稿受理 : 1986年 3 月 12 日)

\section{1. 緒}

言

加硫ゴムの力学物性と網目構造との関連性について, 理諭, 垁 験の両面からさまざまな検討がなされている1). 特に近年, モデ ル網目の合成が容易となり，貴重な知見が多く見い出されてい る2). しかし通常の加硫ゴムの場合は，網目構造自体がまだよく わかっていない, 網目構造の定量化に際して, 特に重要なパラメ

$*$ 東北大学非水溶液化学研究所 $\overline{7} 980$ 仙台市片平 $2--1-1$
ータとして架橋度（架橋点間平均分子量の逆数に比例）と架橋点 の官能基数がある. これらの物理量の決定法として, 従来からゴ 厶弾性理論に基づく, 応力-歪測定や膨潤法が採用されている. しかしながら，上述のモデル網目を用いた赛験結果から，古典的 ゴム弾性理諭のイメージは大きく変更をよぎなくされて打り， Flory らを中心に理論の大幅な修正が行われている1). 本論文で 述べる氷点降下法も加硫ゴムの架橋度を決定する力法として考案 されたもので, 加硫ゴムを良溶媒中で平衡膨潤状態にした後, 膨 
潤試料を冷却し，膨潤媒の水点降下度を測定する方法で方る ${ }^{3)}$. しかしその理論的背景は他の力学的方法とは大きく異なる。これ までの著者らの一連の実駼結果から，この方法は架橋度の評価よ りむしろ加硫ゴム本来の網目構造の不均一性（架橋点間平均分子 量分布）を明確に区別できることが明らかとなっだ)。ところが, この承点降下度は通常の希薄溶液に怙ける束一的効果では説明が できない程大きいものである4).

本論文では, 膨潤加硫ゴムのこの大きな水点降下現象を説明す るために，ポリジメチルシロキサン骨格のモデル網目及びその未 架橋状態の溶液を用いて, 承点降下現象の支配因子について詳細 に検討した。

\section{2. 実 験}

本研究に用いた物質は，両末端ジビニルポリジィチルシロキサ ン (PDMS), 天然ゴム (NR；ペール・クレープ, №.1), スチレ ン含有量の異なるスチレンーブタジェンゴム (SBR), シス-1, 4-ポ リブタジェン (PB) とポリスチレン (PS) である。測定用試料 は各種ゴムのベンゼン溶液とベンゼン中で膨潤させた架橋ゴムで ある。両末端架橋 PDMS 試料は Table I に示すように, 4 種類
調整した．架橋羭としてテトラジメチルハイドロシロキシシラン, $\left[\mathrm{H}\left(\mathrm{CH}_{3}\right)_{2} \mathrm{SiO}\right]_{4} \mathrm{Si}$ を用い, 白金触媒, $\mathrm{H}_{2}\left[\mathrm{PtCl}_{6}\right] \cdot 6 \mathrm{H}_{2} \mathrm{O}$ の存在 下, 窒素中, $373 \mathrm{~K}$ で24時間加熱して架橋した。 架橋した試料は ベンゼン抽出後 (48時間), 真空乾燥した ${ }^{2}$. プレポリマーの数平 均分子量, $\bar{M}_{\mathrm{n}}$ は GPC 法及び Wij's 法 ${ }^{5}$ (ヨウ素間接滴定法に よる末端基定量法の一種）で求め，両者の方法による值はよい一 致をみた。

また，Table I に示した試料 A，Dに用いたプレポリマーを Table II そ示すような割合で混合させて同様に架橋した。これに より Table I に示す均一モデル網目と Table II に示す不均一モ デル網目が得られる ${ }^{6)}$.

水点降下度 ${ }^{4}$, 固有粘度の測定は，既に報告されている方法で 行った.

膨潤試料の圧縮応力の温度依存性は Fig. 1 (a), (b)に示す自作 の装置で測定した。(a)は装置の全体図，(b)は試料部の拡大四であ る。(b)に示与ように上部ジッパー ( UZ) と下部ジッパー (LZ) は 同じ型をして招り，両者は三次元空間内で同一中心線を有し，上 下の横棒は互いに㨁角にクロスしている，この点をわかりやすく するために，(a)では上部ジッパー，下部ジッパーに関しての及斜
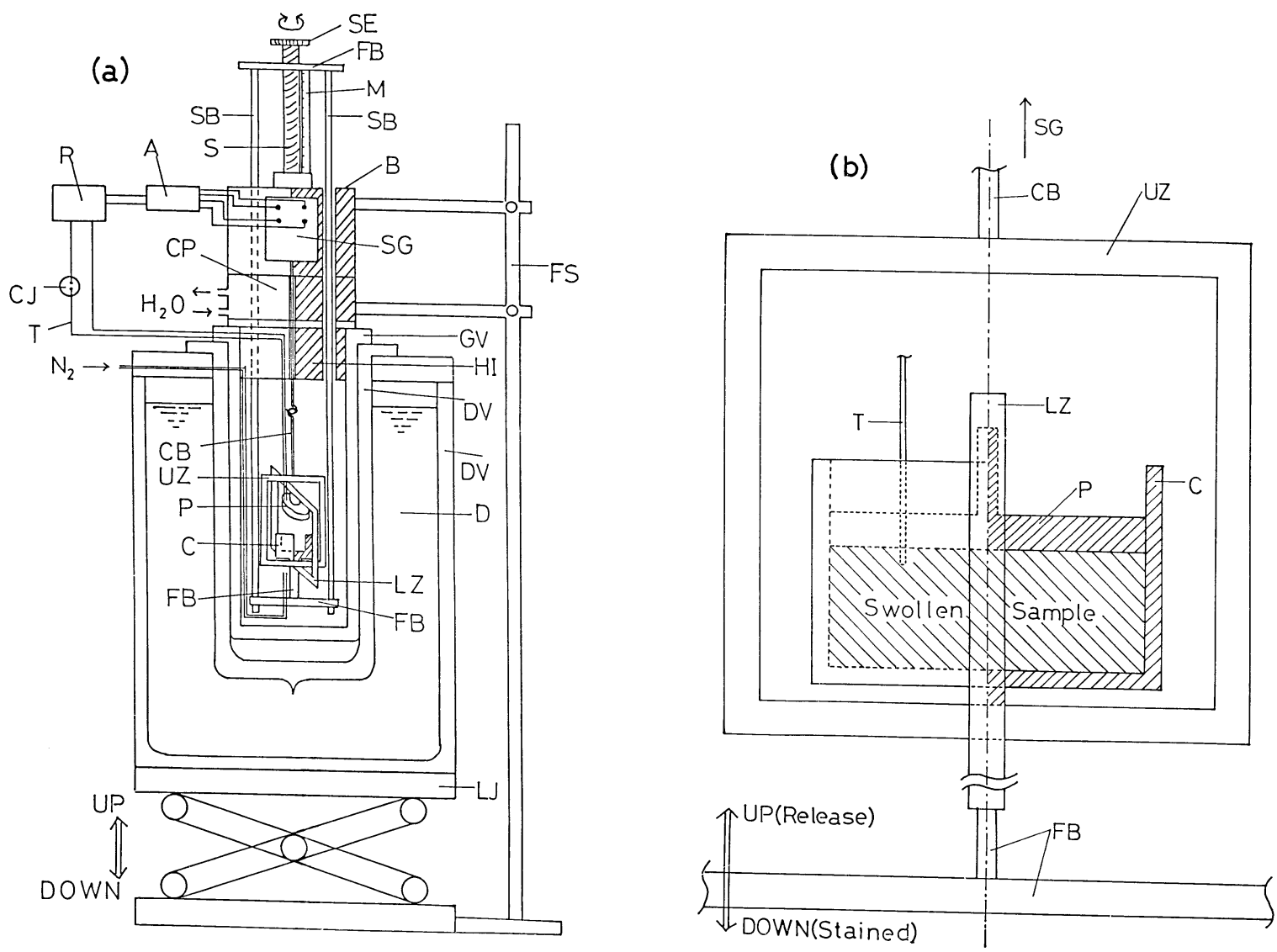

Fig. 1 (a) The scheme of the instrument for measurement of the dependence of the compressive force on temperature for swollen rubber vulcanizates: $\mathrm{A}$, amplifier; $\mathrm{B}$, body ; $\mathrm{C}$, cylinder ; $\mathrm{CB}$, combination bar : $\mathrm{CJ}$, cold junction ; CP, cooling part ; D, dry-ice acetone bath ; DV, Dewar vessel ; FB, fixation bar ; FS, fixation stand; GV, glass vessel; HI, heating insulator; LJ, labo-jack; LZ, lower zipper ; M, measure ; $\mathrm{P}$, piston ; $\mathrm{R}$, recorder ; $\mathrm{S}$, screw ; $\mathrm{SB}$, slide bar; $\mathrm{SE}$, strain-endowment instrument ; $\mathrm{SG}$, strain gauge; $\mathrm{T}$, thermocouple ; UZ, upper zipper.

(b) The magnification figure of the cylinder (C) and piston (P) part of the instrument in (a), and the load of the swollen sample is schematically shown. 
Table I. Polydimethylsiloxane samples of unimodal network.

\begin{tabular}{cccccc}
\hline \multirow{2}{*}{ Sample } & \multicolumn{2}{c}{$M_{n}\left(\mathrm{~g} \mathrm{~mol}^{-1}\right)$} & Vinyl content & Number of vinyl & \multicolumn{2}{c}{$\begin{array}{c}\text { Extent of reaction } \\
\text { groups per chain }\end{array}$} \\
\cline { 2 - 6 } & GPC & Wij's Test & $(\%)$ & 1.8 & 90.2 \\
A & $2.36 \times 10^{3}$ & $2.64 \times 10^{3}$ & 89.4 & 1.9 & 92.7 \\
B & $9.36 \times 10^{3}$ & $9.76 \times 10^{3}$ & 95.8 & 2.0 & 70.1 \\
C & $1.59 \times 10^{4}$ & $1.13 \times 10^{4}$ & 99.9 & 2.0 & 79.2 \\
D & $4.19 \times 10^{4}$ & $4.08 \times 10^{4}$ & 99.9 & & \\
\hline
\end{tabular}

* Pt-catayst : 5 10 ppm elemental Pt relative to the total weight of reactants.

Table II. Polydimethylsiloxane samples of bimodal network.

\begin{tabular}{|c|c|c|c|c|}
\hline \multirow{2}{*}{ Sample } & \multicolumn{2}{|c|}{ Content of sample A } & \multirow{2}{*}{$\begin{array}{r}M_{n} \text {, calc. } \\
\left(\mathrm{g} \mathrm{mol}^{-1}\right)\end{array}$} & \multirow{2}{*}{$\begin{array}{c}\text { Extent of reaction } \\
(\%)\end{array}$} \\
\hline & wt $\%$ & $\mathrm{~mol} \%$ & & \\
\hline $\mathrm{AD}-2$ & 80 & 98.3 & $3.71 \times 10^{3}$ & 88.0 \\
\hline $\mathrm{AD}-4$ & 60 & 95.7 & $5.08 \times 10^{3}$ & 87.6 \\
\hline $\mathrm{AD}-6$ & 40 & 90.8 & $7.64 \times 10^{3}$ & 79.3 \\
\hline $\mathrm{AD}-8$ & 20 & 78.9 & $1.39 \times 10^{4}$ & 72.0 \\
\hline
\end{tabular}

めから見た図として描いてある。上部ジッパーの低部にはシリン ダ(C)が取付けてあり，上部ジッパーはその上端でストレイン・ ダージ (SG) 飞連結棒 (CB) を介してぶらさがっている.一方 下部ショッ゚ーの上部には, シリンダと対応するようにピストン (P)が付けられて和り，下部シッッパー自体は固定棒 (FB) に固定 されている. 固定棒は歪賦与装置 $(\mathrm{SE})$ を回転することによって 上下する，つまりピストンが上下し，シリンダ内の膨潤試料に歪 が加えられる. シート状の加硫ゴム試料（厚さ約 $1 \mathrm{~mm}$ ) をベン ゼン中で48時間膨潤させ, 平衡膨潤状態に達した後, シリンダの 内径 $(10 \phi)$ と同一直径の円柱型打抜き器（自作）を用いて, ゼン ゼン中で膨潤試料を打抜く. 打抜かれた円盤状の試料の表面のべ ンゼンをろ紙で速やかに軽くふきとり, シリンダ内に装媜し，ピ ストンでふたをする。つまり，膨潤試料の直径とシリンダの内径 は同一であるので，歪を加えたとき，膨潤試料は圧縮方向と直角 方向に膨張することはできない。すなわち，この測定は単純圧縮 試験ではない。これは膨潤試料の乾燥による体積分率変化をでき るだけ妨ぐ目的で，膨潤試料とシリンダ壁の間に空間を作らない ようにしたためである. 压縮応力はストレイン・ゲージで検出し， 同時にピストンの先端に出ている熱電対 $(\mathrm{T})$ で試料温度を測定し, 記録計 $(\mathrm{R})$ 亿同時に記録する. 圧縮比は約 0.99 程度である. ここ で, 圧縮比=シリンダ内で圧縮された膨潤試料の嬮さ/王縮前の 膨潤試料の厚さと定義した. 歪賦与後, ただちにドライアイスー アセトンバス (D)中に没入させてあるデュアビン (DV)をラボジ ヤッキ $(\mathrm{LJ})$ で押上げ，その中に試料部を装入し，冷却寸る。冷 却速度は約 $1 \mathrm{~K} \operatorname{~nin~}^{-1}$ である。

\section{2. 結果 と考 察}

Fig. 2 に均一及び不均一架橋 PDMS 試料をベンゼン中で膨潤 させたものと, PDMS-ベンゼン溶液の膨潤媒（ベンゼン）の氷 点を示す. ゴム分の体積分率の増加, 及び架橋度の增加とともに 氷点は大きく降下する，膨潤試料の場合は，同一体積分率の溶液
の場合よりも著しく降下する。このことから明らかに架橋試料で のこの現象は, 溶液の場合と異なって, 単に濃度だけでなくゲル 効果（具体的内容については後述する）が重要な役割を果たして いることが推測される ${ }^{4)}$.さらに不均一架橋試料の場合は均一架 橋試料よりも低い氷点を示す. 本実験で調整した不均一架橋試料 では，実験の部でも述べたように，平均分子量の異なる 2 種類の プレポリマーをあらかじめ適当な㓶合いで混合し，それぞれのプ レポリマーの両末端で架橋して網目が形成される.つまり 1 種類 のプレポリマーから形成される均一網目に比較して (各プレポリ マーの分子量分布は 2 以下である), 不均一架橋試料の架橋点間 平均分子量の分布は広い, 換言すると不均一架橋試料では, 網目 のメッシュサイズに分布があり，より小さなメッシュ中にトラッ プされたベンゼンの結晶化のための核形成・成長が困難となり, 系全体の水点がより低下するものと定性的には考光られる4 . ま た, 低温 DSC (示差走查熱量計) を用いて, 冷却速度を 0.625 $10 \mathrm{~K} \mathrm{~min} \mathrm{~m}^{-1}$ の範囲で变えた場合, 水点には系統的な変化が見られ ず，実験䛊差範囲内で一定值であった $\overbrace{}^{7)}$.つまり，いずれの試料 の水点も核涪平衡值とみなせる.

このような氷点降下現象に影響を与える因子として, 濃度, 平 均分子量, 溶媒とポりマーの相互作用 ( $\chi$ パラメータ) が考光ら れる.濃度についての一般的傾向は, 既に Fig. 2 で述べたので,

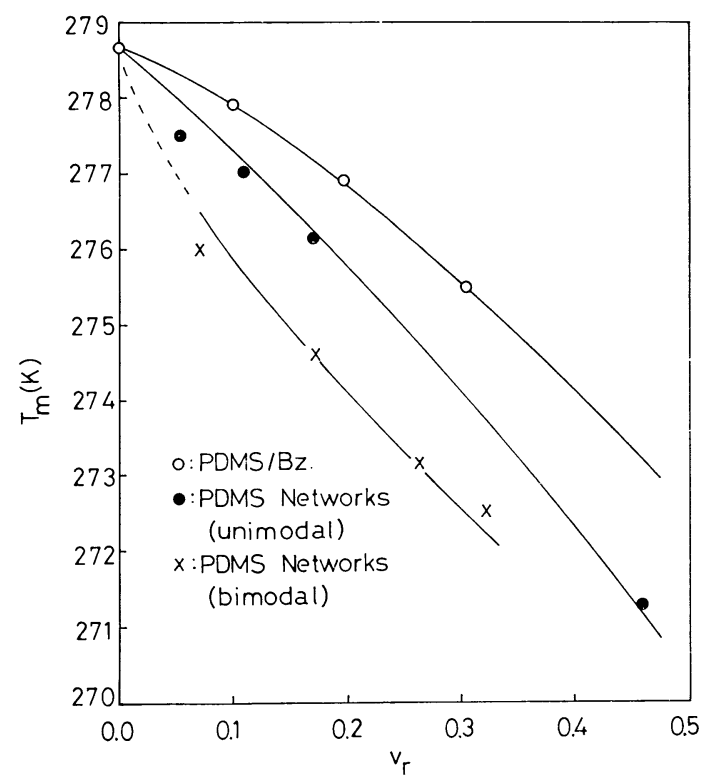

Fig. 2 The dependence of the freezing point, $T_{\mathrm{m}}$, on the volume fraction of rubber, $v_{\mathrm{r}}$. 
他の因子について以下で順に議論する.

まず膨潤ゲルの問題に入る前に溶液系について考察する．Fig. 3 は，種々のポリマーのベンゼン溶液の水点降下の様子を示した ものである. 当然, 体積分率の増加とともに氷点は降下するが, 降下の程度はポリマーの種類によって異なる。一般にベンゼンと の相溶性のよい組み合わせ ${ }^{8)}$, つまり $\chi$ パラメータが小さい程, 降下は大きい，同様な傾向はスチレン含有量の異なる DCP 加硫 SBR 試料にも見られた ${ }^{9)}$.

一方, Fig. 4 は PDMS のベンゼン溶液での氷点降下度, $\Delta T$ の分子量依存性を示寸. 平均分子量が $10^{4}$ 以上であれば, $\Delta T$ は 分子量に依存せず，もっぱら体積分率によっての及決定される. この結果は, 逆にこの氷点降下現象が通常の希薄溶液に拈ける束 一的な効果では説明ができないことを示唆する。また，一番平均 分子量の低いPDMS試料では, 同一体積分率ながら, 他の高分子

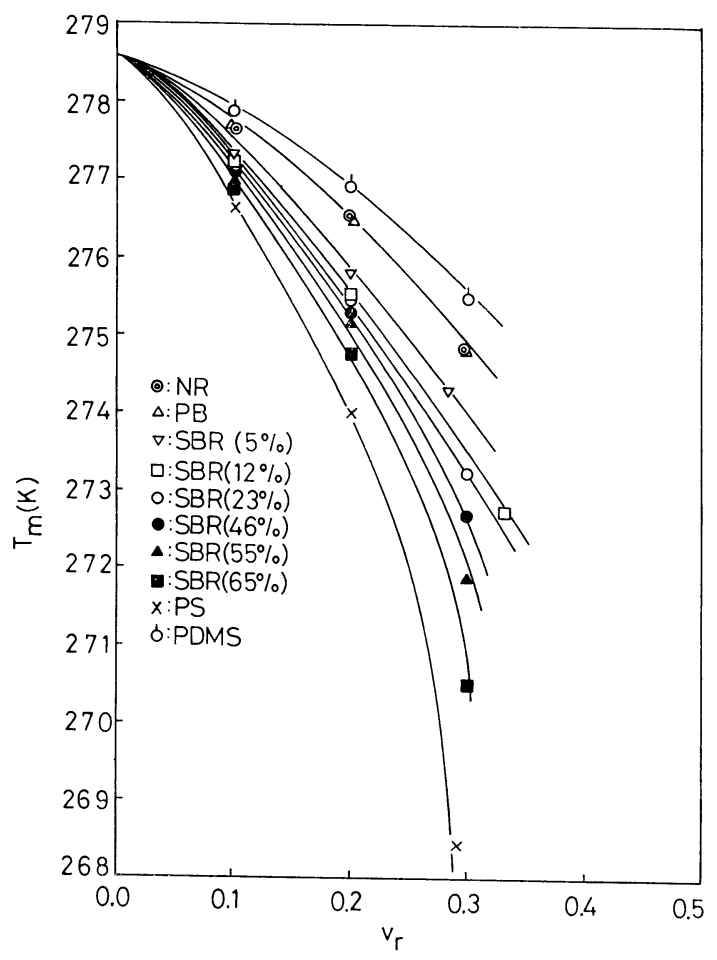

Fig. 3 Plots of $T_{\mathrm{m}}$ vs. $v_{\mathrm{r}}$ for various" polymer solutions of benzene.

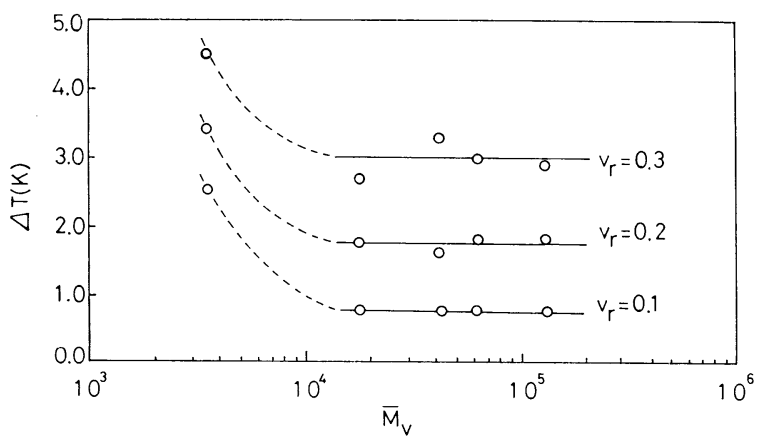

Fig. 4 Relationship among the degree of freezing point depression $\Delta T$, the average molecular weight $\bar{M}_{\mathrm{v}}$, and $v_{\mathrm{r}}$ for PDMS in benzene.
量試料よりも大きな降下度を示す，両試料の状態の違いを定性的 に調べてみると，同一体積分率ではあっても，高分子量溶液はい わゆる重なり濃度 ${ }^{10)} ， C^{*}$ 以上の領域，つまり準希薄溶液である のに対して，一番平均分子量の低い試料では，この試料の重なり 濃度を体積分率に換算すると約 0.4 で, 希薄溶液に相当する. 高 分子量側の試料つまり準希薄状態で $\Delta T$ が分子量依存性を示さな いことは，この濃度域での浸透圧がもっぱら重量濃度によっての み決定されていることと類似している ${ }^{10)}$.

さらに Fig. 5 には, Fig. 4 で示した一番平均分子量の低い試 料の $\Delta T$ と, 重量濃度 $C_{\mathrm{e}}$ の両対数プロットを示す.やはりこ の場合でも, 濃度の增加とともに $\Delta T$ は大きくなるが, その程度 は $C^{*}$ 以上の濃度域で急に大きくなる。しかしながら， $\Delta T$ と $C_{\mathrm{e}}$ の両対数プロットが，2本の直線で近似できる論拠については, 以下でも述べるように，この現象の原因そのものと関連すること で,ささら検討を要するところである.

以上の溶液系での結果をまとめると, 氷点降下度は, 体積分率 もしくは重量濃度の高い程, また メパラメータの小さい程, そし て重合度が低い程, 大きくなる。この現象も相分離の一種である と考光れば，平衡氷点は， 2 相の化学ポテンシャル $\Delta \mu_{1}$ が等しく なるところで決定される，ここで溶液系の溶媒の $\Delta \mu_{1}$ を格子模型 を用いた Flory-Huggins の式で記述すると ${ }^{11)}$ ，

$$
\begin{aligned}
\Delta \mu_{1} & =R T_{\mathrm{m}}\left[\ln \left(1-v_{\mathrm{r}}\right)+\left(1-N^{-1}\right) v_{\mathrm{r}}+\chi(T) v_{\mathrm{r}}{ }^{2}\right] \\
& =-\Delta H_{\mathrm{m}}\left(1-T_{\mathrm{m}} \cdot T_{0}^{-1}\right)
\end{aligned}
$$

となる．ここで， $\Delta H_{\mathrm{m}}$ は融解エンタルピー， $R$ はガス定数， $T_{0}$ は標準水点. また $\chi$ パラメータは温度の関数としてある. この式 (1)で，既述の $\Delta T$ 亿関する実験結果を定性的には説明することが

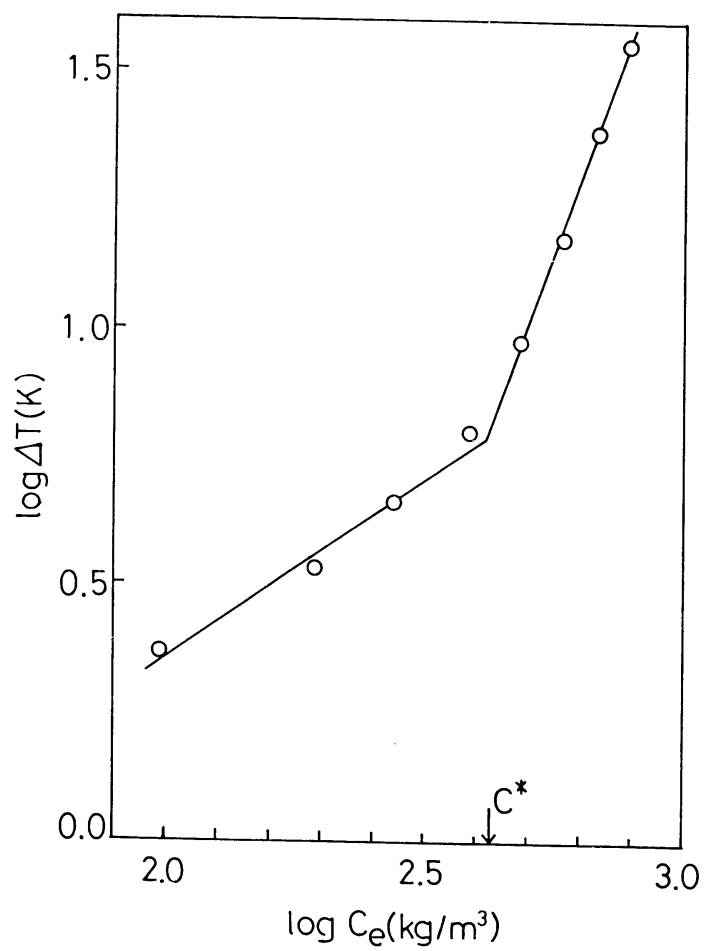

Fig. 5 Plots of $\log \Delta T$ vs. $\log C_{\mathrm{e}}$ for the prepolymer of Sample A. $C_{\mathrm{e}}$ is the weight concentration of polymer solution. 
できる。つまり， $v_{\mathrm{r}}$ が高くなり， $\chi(T)$ が小さい程， $\Delta T=T_{0}-$ $T_{\mathrm{m}}$ は大きくなる．また， $N$ が大きい程， $\Delta T$ の值そのものは小 さくなり, かつ $\Delta T$ の変化率は鈍化して, 重合度依存性は低くな る.しかしながら, Fig. 6 亿示すよ5に, 実験結果と計算曲線に は大きな差異がある.Fig. 6 での実験データはNR-ベンゼン溶 液の場合で， $\chi=0.38$ としてある ${ }^{12)}$. NR の実際の重合度は， $N$ $\doteqdot 1400$ である。この溶液の $C^{*}$ 濃度を重なり体積分率 $v_{\mathrm{r}}$ 亿換算 すると, 大体 0.02 程度である.つまりこの実験は $C^{*}$ 濃度以上で 行われ, 計算曲線との比較を行っている。叱值は一般に温度が 降下するとともに大きくなる11)。この温度效果を考慮すれば，計 算曲線と実験結果との差はむしろ大きくなる傾向にある.

一才, 膨潤試料の一定歪下に怙ける压縮応力の温度依存性を Fig. 7 に示した。この場合, 実験の部で詳細に述べたように, シ リンダの内径と同一直径の膨潤試料をベンゼン中で打抜き，シリ ンダ内に装媜した後, できるだけ膨潤試験の乾燥を妨ぐために, すみやかに上からピストンで歪を加え, ただちに試料の冷却を開 始した。 そのため初期での応力減少には温度降下と応力緩和の相 方の要因が重畳していると考兄られる。陚料が凍結すると，Fig. 7 に示したよ5に圧縮応力は零となり, 巨視的な意味でのゴム弾 性は示さなくなる。このような状態であっても, NMR の測定か ら凍結試料でありながら，内部のゴム分子鎖は，室温下と同程度 に活発な熱運動をしている4)。一般に膨潤ゲルの弾性率 $E$ が浸透 圧 $\pi$ の体積分率微分で与兄られることは, 結局, 次式のよ5に自 由エネルギーFの 2 階微分といらことになる ${ }^{10)}$ 。つまり

$$
E=v_{\mathrm{r}}\left(\partial \pi / \partial v_{\mathrm{r}}\right)_{T}=v_{\mathrm{r}}\left(\partial^{2} F / \partial v_{\mathrm{r}}{ }^{2}\right)_{T}
$$

Fig. 7 で王縮応力が零になった場合，膨潤試料の弾性率も零にな

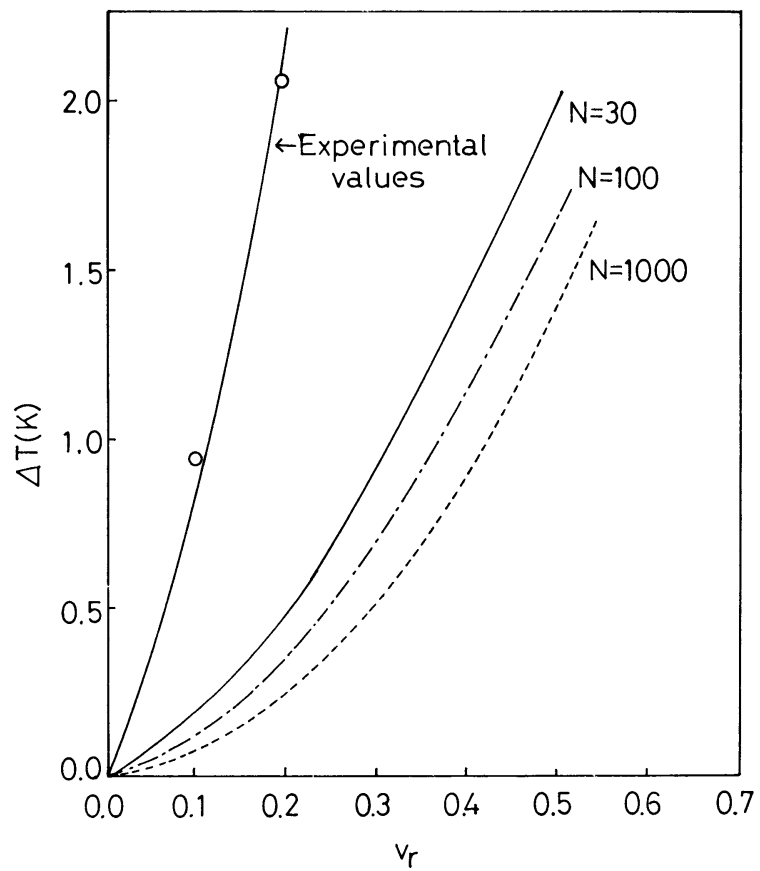

Fig. 6 Comparison of the experimental values of $\Delta T$ with those calculated from eq. (1). The experimental values are for NR solutions of benzene. Cross-over volume fraction of rubber, $v_{\mathrm{r}}{ }^{*}$, estimated from the cross-over concentration is approximately equal to 0.02 .
ると思われる。式(2)を適用すれば，この相分離の初期過程がスピ ノダル分解ということになる. しかし，形態観察も行わないで， Fig. 7 の結果からだけで，スピノダル分解であると断定するのは 無理である。 また Fig. 2 のところで述べたように, 冷却速度依 存性がたいこととも矛盾する。むしろ, Fig. 7 で応力が零になる 理由として，膨潤試料の凍結時に扣ける収縮のためと考えた方が 妥当である. Fig. 7 亿示した压縮応力が零になるここに関しての 圧縮歪依存性についてであるが，本実験では幅広くその依存性を 調べていない，しかし，実験の部で定義した压縮比にして，0.99 〜0.95の範囲では圧縮歪依存性は観測されなかった。つまり， Fig. 7 での実験結果は圧縮比が0.99のときの值であるが, 他の圧 縮比でも各試料の压縮応力は, 実験誤差範囲内の同一温度で零と なった。

水溶性ポリアクリルアミドゲルではスピノダル分解によって異 常な膨润げルの収縮が観測されている ${ }^{13)}$. 本実験にお打る現象も Fig. 7 に示すよ5に压縮応力が零となることから，相転移による 膨潤ゲルの収縮が示唆される。しかしながら，既述のように，こ こでの収縮機構がスピノダル分解によるものと直接結びつけるこ とはできない，なぜならば，水溶性ダルで観測されたスピノダル 分解による体積収縮は, 温度あるいは濃度（溶媒組成比）の変化 によって, ある臨界点に達すると, 離散的に体積が収縮し, 条件 によっては $1 / 100$ 程度に縮む. だが，このような離散的収縮はそ のゲルの架橋度がきわめて高いときに生じると理論的に予測され ている ${ }^{14)}$. 技そらく, 水溶性ポリアクリルアミドゲルでは化学的

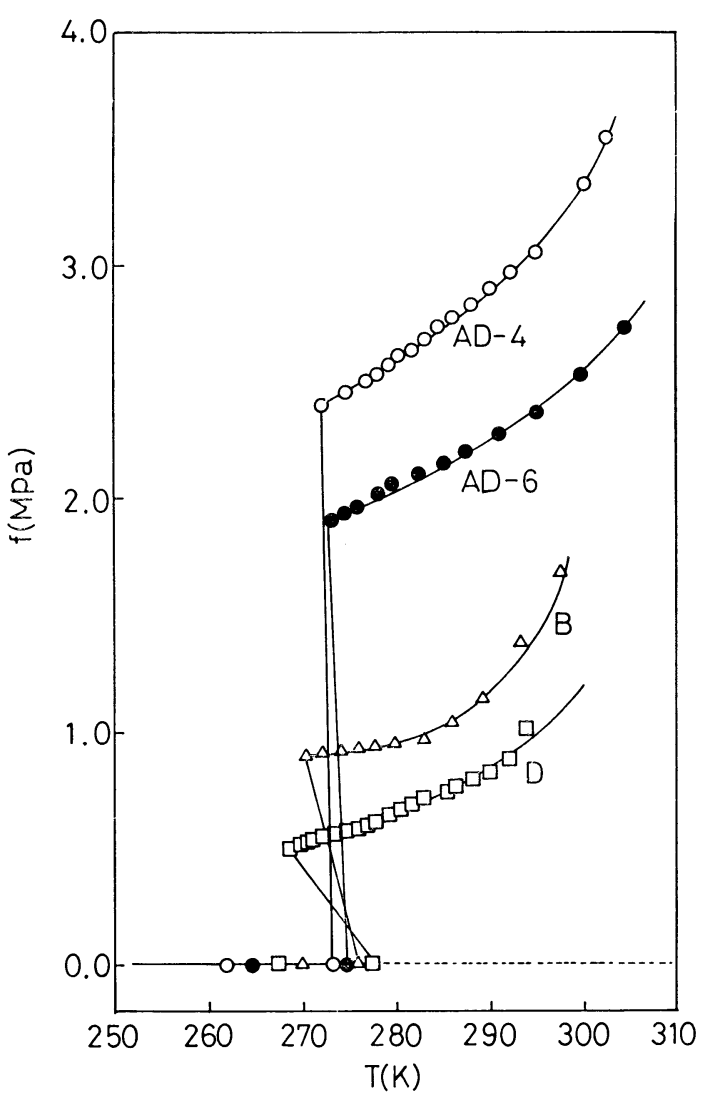

Fig. 7 The dependence of compressive force on temperature for swollen unimodal and bimodal PDMS networks. 
架橋のほかに, 静電相互作用が膨潤グルの弾性（架橋度）に重要 な役割を果たしているので, 実質的に高架橋状態にあるので実現 されるものと思われる。これ刘して本赛験の場合は，むしろ温 度降下に上る溶嬠の貧溶媒化とそれに伴らゴム分子鎖の偏析効果 による網目の局所的収維が膨潤ゲル中のいたる所で生じている中 で (一種の $\theta$-転移であり， ミクロシネリシスとも考えられる $\left.{ }^{14)}\right)$, ベンゼンの結晶化が生じるものと思われる。つまり，ここで取报 っている膨潤ゲルの氷点降下現象も一種の相転移ではあるが，そ の中味は一定降温速度下での温度降下による膨潤ゲルの $\theta$ 転移と, それに続くベンゼン溶媒の結晶化という機構であると考えられる。 おそらくこの機構によって, 膨潤試料の凍結時にマクロな収縮が 生じ, 圧縮応力が零になるものと思われる. 以下で, このベンゼ ンの結晶化直前のゴム溶液あるいは膨潤バルの状態についてさら に議論をする。

Fig. 8 は平均分子量の異なるPDMS のベンゼン溶液の固有粘 度 $[\eta]$, 膨潤試料の $v_{\mathrm{r}}$ の温度依存性を示してある。温度降下

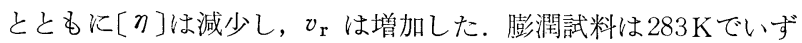
れも白濁した．おそらくこの温度付近から，既にFig. 7 での議論 のところで述べたような膨潤ゲルの $\theta$-転移が生じるために白濁 が生じると思われる. 本実験では膨潤ゲルの体積分率の温度依存 性を Fig. 8 に示したように, 便宜的に 4 点で測定した。このた め, たまたま $283 \mathrm{~K} て ゙$ 白濁が観測されたが，この温度を相分離が 開始する温度とみなすことはできない。また Fig. 2 に示した膨 潤ゲル中のベンゼンが凍結する温度と, Fig. 7 亿示した圧縮応力 が零となる温度は, 実験誤差範囲内で等しいが, まだ実験的に系 全体の相図が判明しているわけではないので, 白濁が生じる 283 K近傍での状態とベンゼンの凍結温度との関係は不明である。し かし，既述のよ5にこの関係は本質的に重要であると思われる。

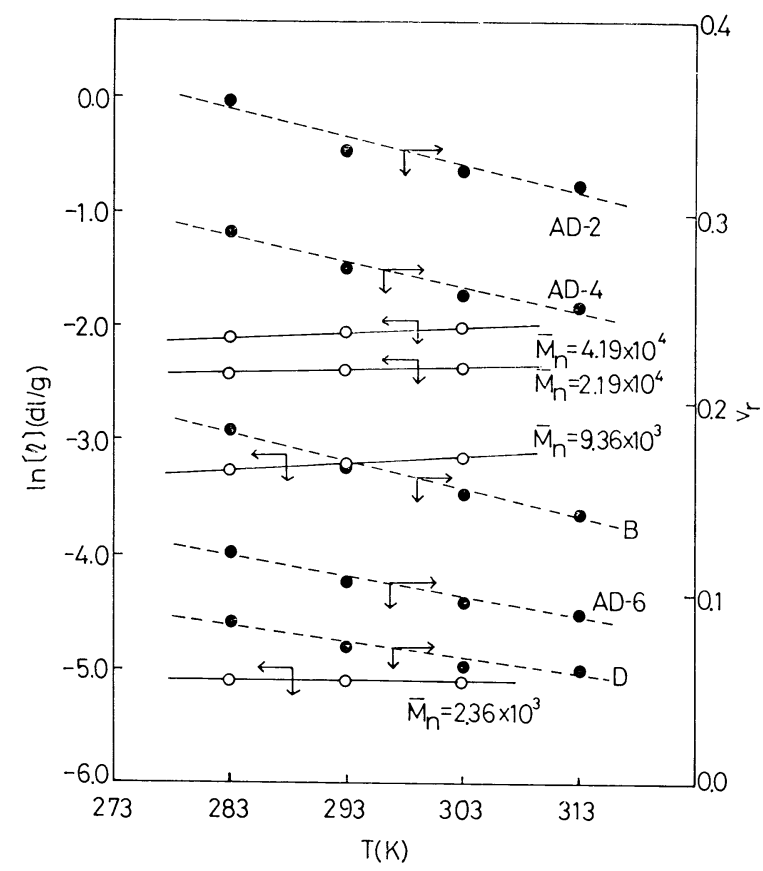

Fig. 8 The changes of the intrinsic viscosity, [ $\eta]$, for PDMS solutions (unfilled circles), and $v_{\mathrm{r}}$ for swollen PDMS networks (filled circles) with lowering temperature.

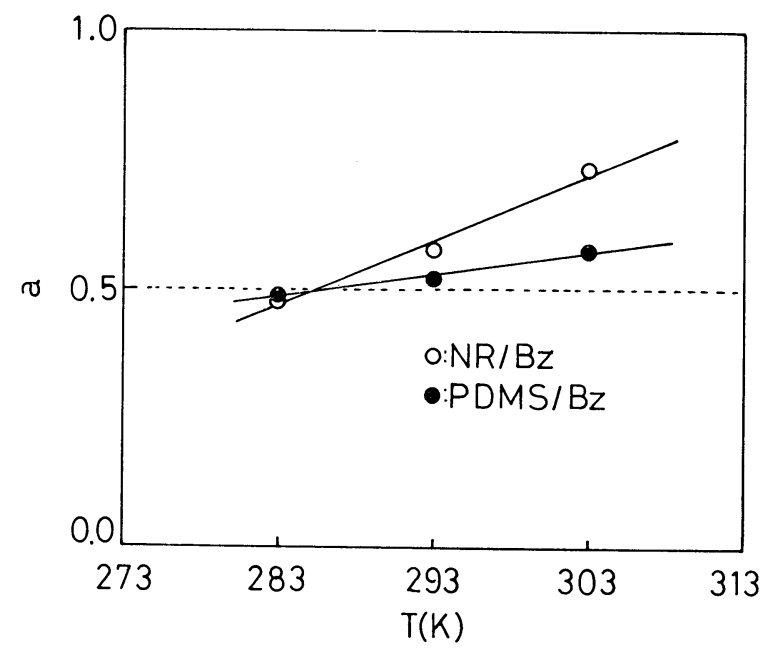

Fig. 9 Relationship between the exponent, $\boldsymbol{a}$, in eq. (3) and temperature.

〔ク]は平均分子量と次式で関係づけられることが知られている $[\eta]=K \bar{M}_{n}{ }^{a}$

Fig. 8 の結果から求めた式(3)中の指数 $a$ の温度依存性を Fig. 9 に示す。ただしこの場合，一番平均分子量の低いPDMS に関す るデータは計算に含めていない. Fig. 9 には併せて NR の場合 の結果も示してある。いずれのゴム溶液でも, 温度降下とともに 貧溶媒化しているのがわかる．また，理想鎖の両末端間距離の温 度係数 $\left(\partial \ln <r^{2}>_{0} / \partial T\right)$ は, PDMS の場合 $1.5 \times 10^{-3} \mathrm{deg}^{-1}$, $\mathrm{NR}$ の場合 $1.8 \times 10^{-3} \mathrm{deg}^{-1}$ となった. 算出に際して具体的数値 があいまいなパラメータもあり，文献值 ${ }^{16)}$ 之若干異なっているが， このような温度係数であるといらことは, 温度降下が $C^{*}$ の増加 に対応し, 溶液の希薄化と濃度分布の不均一性, つまり偏析化を 意味する．固有粘度測定に用いた溶液の濃度と，これまで議論の 刘象としてきた溶液の濃度とは全く異なるが，既述のような偏析 効果は生じているものと思われる。一方，膨潤試料に叔ける体積 分率の增加は平衡状態での話であり，一定降温速度で泠却した膨 潤試料の状態とは本質的に区別されるものである. 明らかに, Fig. 7 に示したような圧縮応力の温度依存性の実験は一定降温速 度下での測定である。さらに，装置の都合上，冷却されつつある 膨潤試料の状態変化を，直接視認できない上に，283 K 付近での 压縮応力に，特別な変化は見られなかった，乙かし，膨潤試料は 収縮しょうと不安定な状態にあると考えられる ${ }^{10,14)}$.

いずれにしても降温によるゴム溶液の偏析効果あるいは膨潤試 料の体積分率の増加は, 内部では液体構造, 膨潤ゲル構造の不均 一性を促進し，系全体に濃度分布が生じる。つ屯り，この氷点降 下現象を定量的に記述するには, 式(1)に示したような単なるマク 口的な体積分率とメパラメータだけでは不十分で，相転移直前の ゴム溶液の液体構造，膨潤ゲルの網目構造の不均一化を考慮しな ければならない。さらに膨潤ゲルの場合は弾性自由エネルギーの 奇与も取入れなければならないと思われる。これらの点を踏まえ て，今後さらに検討を加える予定である.

（本論文の大部分は，1985年10月10日，第33回レオロジ一討論 会飞て発表) 


\section{文献}

1) Flory, P.J., and B. Erman, Macromolecules, 15, 800, 805 (1982).

2) Llorente, M.A., and J.E. Mark, Macromolecules, 13, 681 (1980).

3) Kuhn, W., and H. Mayer, Angew. Chem., 68, 345 (1956).

4) Oikawa, H., and K. Murakami, Polymer, 25, 225, 1117 (1984).

5) Llorente, M.A., A.L. Andrady, and J.E. Mark, $J$. Polym. Sci., Polym. Phys. Ed., 18, 2263 (1980).

6) Andrady, A.L., M.A. Llorente, and J.E. Mark, J. Chem. Phys., 72, 2282 (1980).

7) Oikawa, H., and K. Murakami, Polym. Prep., Jpn., 35, 1034 (1986).
8) J. Brandrup, and E.H. Inımergut, "Polymer Handbook", (1975), John Wiley \& Sons, New York, Chap. 4.

9) Oikawa, H., and K. Murakami, Polymer, 27, 389 (1986).

10) P.G. de Gennes, "Scaling Concepts in Polymer Physics", (1979), Cornell Univ. Press, Chaps 3 and 5.

11) Flory, P.J., J. Chem. Phys., 10, 51 (1942).

12）渡辺茂隆，ゴム協誌，34，787 (1961).

13) Tanaka, T., Phys. Rev. Lett., 40, 820 (1978).

14) Hsu, T.-P., and C. Cohen, J. Polym. Sci., Polym. Lett. Ed., 23, 445 (1985).

15）桜田一郎, 化緎講演集, 6, 177 (1941).

16) Mark, J.E., and P.J. Flory, J. Amer. Chem. Soc., 86, 138 (1964). 